\title{
Small and Medium Sized Entities Management's Perspective on Principles-Based Accounting Standards on Lease Accounting
}

\author{
Jierong Cheng \\ Department of Business College of Technology, City University of New York, New York, USA \\ Email: JCheng@citytech.cuny.edu
}

Received 15 January 2015; accepted 13 February 2015; published 16 February 2015

Copyright (C) 2015 by author and Scientific Research Publishing Inc.

This work is licensed under the Creative Commons Attribution International License (CC BY). http://creativecommons.org/licenses/by/4.0/

c) (i) Open Access

\begin{abstract}
Lease accounting is viewed as one of the top priorities for the International Financial Reporting Standards (IFRS) convergence. Small and medium sized entities are an important part of the economy, and this research investigates the management's perspective on the adoption of principles-based IFRS about lease accounting. This researcher interviewed four managers from three different small and medium sized entities, and found the management to be more concerned about their long-term business success than the change of accounting standards. Only when the entities have a loan with the bank, then the management focuses on the lease classification. The interview also suggests that the managers and business owners in the small and medium sized entities have limited knowledge and skills in accounting reporting standards. These firms outsource their accounting needs to local accountants rather than having their own in-house departments. The other aspect of focus for management of these firms is tax consequence of IFRS adoption. The research suggests other regulatory agencies, i.e., Internal Revenue Service, should also be involved in enhancing financial statement transparency and usefulness after the adoption of accounting standards.
\end{abstract}

\section{Keywords}

International Financial Reporting Standards (IFRS), US General Accepted Accounting Principles (GAAP), Lease Accounting, Small and Medium Sized Entities (SME)

\section{Introduction}

This study examines small business managements' perspective on the convergence of accounting standards to 
International Financial Reporting Standards (IFRS) from US Generally Accepted Accounting Principles (GAAP). As the world continues to migrate towards an interconnected economy, the market recognizes that it is easier to have one set of accounting rules to record economic transactions and facilitate cross-border capital flows. The Financial Accounting Standards Board (FASB) has been working closely with the International Accounting Standards Board (IASB) to improve and converge US Generally Accepted Accounting Principles (GAAP) to International Financial Reporting Standards (IFRS) in the past decade. This study analyzes US GAAP and IFRS lease accounting's impact and the management's view on such implementation.

The study uses the FASB definition of small and medium sized entities (SMEs), which are entities that are not subject to public accountability and do not have financial statements filed with a securities commission (e.g. SEC) or other regulatory agencies. Most businesses conform to this definition, and the study of SMEs is important to understand the impact of IFRS on the backbone of economy.

The adoption of IFRS elicits many controversial debates regarding the costs and benefits of convergence. The main concern is the potential increase in management manipulation of financial statements since less specific principles-based accounting standards allow aggressive reporting opportunities. In addition, accounting principles that rely more heavily on managements' interpretation and accountants' judgment in principles-based accounting standards could decrease the comparability among the firms. Conversely, many also argue that the current rules-based accounting model has allowed management to exploit financial accounting engineering to achieve a preferred accounting treatment.

Under GAAP reporting, accounting principles are clearly set into rules. Management and auditors are required to follow the "bright-line" definition. For example, the FASB's Statement of Financial Accounting Standards (SFAS) No. 13, Accounting for Leases, lists four explicit criteria for lease classification. SFAS No. 13 was set down to avoid individual judgment in interpreting lease accounting and to have consistent applications across the firms [1]. One can argue that entities following precise standards are easier for comparison. However, the nature of the precision rules-based accounting standards provided incentive-consistent standard interpretation and achieved preferred accounting treatments [2]. In this case, firms were able to structure lease terms to prevent capitalization, which removed the lease liabilities from their balance sheets and improved their overall financial position [3]. Aggressive utilization of this method can be classified as "financial engineering" in the rules-based regime and manipulation of financial statements. Regulators and the overall market generally recognize that the classification of operating leases is one of the common forms of off-balance sheet financing for the lessee. The asset and liability are not recorded, so the lessee only needs to report the rental expense under the current GAAP standard. An operating lease does not impact any critical financial ratios, so it is a preferred classification for the firms that must report and operate under debt covenant restrictions. With all the above reasoning, the classification of the lease is an important topic for academic investigation.

If a hypothetical lease were constructed precisely according to the SFAS No. 13 standard that does not fall under capital lease, the auditors would have no room to disagree. Auditors are generally reluctant to inquire for more information and use professional skepticism once the lease term fits the definition under SFAS 13. The principles-based standard classifies a capital lease as "(lease that) transfers substantially all the risks and rewards incidental to the ownership” (IAS 17). The auditors' judgment is much more significant under IFRS since they would need to identify the circumstances and threshold that transfers "substantially" all the risks and rewards. Without a holistic understanding of the economic substance and good judgment, the auditors could not classify the lease to correctly reflect the economic reality. The adoption of IFRS is deemed to facilitate the reduction of asymmetric information in the market. As Daske et al. point out, the benefit of transparency and reduction of information asymmetry results in market liquidity and lower cost of capital [4].

This paper contributes to the literature by complimenting the understanding of the cost and benefits of IFRS from SMEs managements' perspective. Extensive studies show that implementation and audit fees would increase substantially at the public companies [5], but little is known regarding the SME managements' strategy to tackle the adoption of the accounting standards and the associated fees. Second, most SMEs are family-owned businesses, so the principle-agent model conflict is not as prevalent as it would be in public companies. SME's are generally more focused on survival in the long-term and passing down the business to heirs. Accounting standards and financial are lower on the priority list and management generally relies on external accountants to provide expertise [6]. This paper explores the field of self-managed businesses in IFRS adoption.

The remainder of the paper is constructed as follows. Section II provides literature review and hypotheses development. Section III describes the interview questions and management response. Section IV provides the 
conclusion, implication, and suggestions for future research.

\section{Literature Review and Hypotheses Development}

The proposed convergence of International Financial Reporting Standards (IFRS) has initiated numerous academic and policy debates. Opponents of IFRS argue that the less specific standards decrease the inter-firm comparability and provide opportunities for financial statement manipulation. The switch to more principlesbased IFRS might provide aggressive accounting reporting opportunities to some management teams since they can interpret the accounting rules with less precise standards [7]. However, studies show that with a strong audit committee and independent external auditor, principles-based standards not only helps to allay the comparability issue across-firms, but they also produce more meaningful economic and financial information [8] [9]. Compared to rules-based standards, principles-based standards generate higher quality financial statements that reduce earnings management, are related to more timely loss recognition and leads to more value relevant accounting measures. This suggests that principles based standards leads to less information asymmetry and aids investors in making informed and unbiased judgments [10] [11]. This results in positive abnormal return and reduction in the cost of capital [12]. Furthermore, Psaros and Trotman [13] found that it would be easier for foreign investment if businesses were reported under IFRS. Many major capital markets (e.g. London, Hong Kong) report under IFRS, reducing information asymmetry and increasing capital flows between borders. This eventually leads to a more efficient capital allocation, allowing both investors and firms to benefit.

The auditors' assessment of the business entities and their underlying economics is important to the process of interpreting accounting standards and evaluating financial information quality. The underlying economic reality is important to assess a firm since it relates to borrowing cost, stock price performance, and other contractual obligations. Some of the common earnings management used to improve the firms' perception of their economic situation includes manipulating accruals [14], and liabilities [15], and lowering goodwill write-off [16]. An operating lease is one of the methods that some management will use to minimize liabilities through financial engineering. The management's perspective is an important piece of knowledge to the puzzle of how IFRS in lease accounting is going to impact capital markets. This paper attempts to close the gap of our knowledge between the management, auditors, and regulators. Table 1 summarized the difference specification for both US GAAP and IFRS. The GAAP has very specific threshold to differentiate between operating lease and capital lease, which is subject to the criticism of financial engineering. While IFRS guideline is too general, and some people disapprove its comparison ability between different firms.

The principles-based accounting standard enables management to apply accounting rules with more flexibility to reflect the economic substance of situations. On the other hand, management can also take advantage of this to report aggressively. The external auditors would potentially have more disagreement over the application of the accounting standard under a principles-based regime. The auditors have more negotiation power when the accounting issues are complex [17]. Auditors are conservative since the damage from loss of reputation is irreparable and litigation costs are onerous, leading them to favor a less aggressive reporting methodology under principles-based standards.

This paper focuses on lease accounting since it is one of the important topics in the convergence of both standards. Management generally prefers to classify leases as operating leases since no lease liabilities are recorded under this designation. This improves debt covenant ratios, facilitates incremental debt capacity, and enhances the financial appearance of the firms. If, under IFRS, the auditors certify management's aggressive accounting

\section{Table 1. Difference between US GAAP and IFRS for lease accounting treatment.}

\begin{tabular}{|c|c|c|}
\hline & US GAAP & IFRS \\
\hline $\begin{array}{l}\text { Lease Standards } \\
\text { Capital vs. Operating } \\
\text { Lease Classify } \\
\text { Definition }\end{array}$ & $\begin{array}{l}\text { Accounting Standards Codification (ASC) } 840 \\
\text { (The lease is considered capital lease if one of the } \\
\text { following term is satisfied. Otherwise, it is an operating lease.) } \\
\text { 1. Transfer of ownership to the lessee at the end of lease. } \\
\text { 2. Bargain-Purchase option allows the lessee to purchase } \\
\text { the property at lower than market value. } \\
\text { 3. Lease period is equal or exceed } 75 \% \text { of the economic life. } \\
\text { 4. Recovery of investment classifies as the present value of the } \\
\text { minimum lease payments equal or more than } 90 \% \text {. }\end{array}$ & $\begin{array}{l}\text { International Accounting Standard (IAS) } 17 \\
\text { (The lease is considered finance lease, } \\
\text { similar to capital lease, if the following } \\
\text { condition is met.) } \\
\text { The accounting standard is based on } \\
\text { principle instead of specific criteria. } \\
\text { The principles indicate whether the } \\
\text { less or transfer substantially all of the } \\
\text { economic benefit and risk to lessee. }\end{array}$ \\
\hline
\end{tabular}


practices without additional due diligence, the potential costs of litigation and loss of reputation are high. Auditors will therefore tend to be more conservative in their practices under principles-based IFRS standards than under comparable GAAP standards. Consequently, contrary to the management's preference, the auditors are more prone to classify the lease as a capital lease. However, management might disagree with the auditors' conservative attitude. In order for the management and the auditors to agree upon on the classification of the lease, the auditors need to understand the underlying economic substance. It is only after performing more substantive testing will auditors understand the substance of the transactions instead of just following numbers and ratios without further questioning. The additional work will result in better understanding of the underlying economic substance for the auditors. Thus, the classification on the financial statements would accurately reflect the "true and fair view" of the lease.

Under IFRS, information disclosure is more robust, including management's assumptions and estimation. Studies show the mandated adoption of IFRS brings comparability and enhances the usefulness of accounting data and improves forecast accuracy [18]. The financial information is perceived to reflect current economic conditions and up-to-date expectations of the future and recognize news in a timely manner [19]. IFRS is substance over form, and the perceived risk is lower, resulting in a potentially lower cost of capital [11].

\section{Interview Questions and Results}

The research includes four interviews from four different managers from three distinctive firms. The mangers are from retail industry, which is representative of typical small and medium size firm population. Unlike financial institutions, retail industry has a combination of capital and operating lease, which is a relatively relevant industry for this research. The gross revenue of the subject manager companies ranged from \$3million to \$28million, with 7 to 56 full time employees. These firms are considered typical small and medium sized entities under IFRS since the corporations are privately owned and do not have accountability to the public. These firms do not have to file with regulatory agency to ensure the general public has access to fairly presented financial statements. The most common governmental agency for which these firms have to present financial information is the Internal Revenue Service in the form of tax returns, though this information is not disclosed to the general public.

The researcher questioned the management of the subject companies on if they would change lease terms for their companies if the accounting standards were to be implemented by IFRS. Since most SMEs are familyowned, and the firms' financial statements are not typically available to external financial users other than regulatory agencies, most typically is the Internal Revenue Service, the management is generally concerned with their long-term profit. "We want our business to continue for the next 20 years, so when we make plans, we plan long term," said one of the interviewees. The same interviewees also prefer to purchase plant and machinery rather than entering into leases. One entity has capital leases on its copy machine and two vehicles and an operating lease for its administrative office space, which is minimal compared to the size of the entity. "The entity also gets a tax deduction if the corporation purchase certain qualified equipment, so I buy most of my machines whenever possible," the manager continued. The management did not intend to use operating lease to leverage financial ratio for this particular entity. Some of the typical interview questions and response are shown in Table 2.

Table 2. Sample interview Q \& A.

\begin{tabular}{|c|c|}
\hline Questions & Answers \\
\hline $\begin{array}{l}\text { What is the ratio of your company's } \\
\text { capital lease to operating lease? }\end{array}$ & $\begin{array}{l}\text { It varies from firm to firm. If the firm owns its own property, the capital } \\
\text { lease is high. Otherwise, the typical firm has more operating lease. }\end{array}$ \\
\hline $\begin{array}{l}\text { Do you have plans to make change about the } \\
\text { lease because of the debt covenant from the bank? }\end{array}$ & $\begin{array}{l}\text { Depends. If the accounting standards increase the cost of capital, } \\
\text { the management considers to modify the lease terms. }\end{array}$ \\
\hline $\begin{array}{l}\text { Does your firm have any accounting } \\
\text { department or hire outside accountant? }\end{array}$ & $\begin{array}{l}\text { It is more cost efficient to hire an outside accountant } \\
\text { compare to hire a full time employee. }\end{array}$ \\
\hline $\begin{array}{l}\text { Will the company suffer from the } \\
\text { change of the accounting standard? }\end{array}$ & Depends on the tax consequences since it might affect the tax liability. \\
\hline $\begin{array}{l}\text { Do you have plans to modify the lease terms because of } \\
\text { the accounting standards change from GAAP to IFRS? }\end{array}$ & $\begin{array}{l}\text { If the benefit were more than the cost of the transaction, } \\
\text { the management would change the lease terms to minimize cost. }\end{array}$ \\
\hline
\end{tabular}


Another manager admitted that the entity preferred operating leases since the corporation has a loan with the bank subject to debt covenants. Debt to asset ratio must be less than $40 \%$; otherwise an additional $5 \%$ interest is imposed on the loan balance. The current ratio is about $36 \%$, and the management prefers not to increase any liabilities if possible. This manager is more concerned about the classification of a lease compared to the manager mentioned above. When this manager was questioned about future expansion of the business, he stated his preference to construct the terms to conform to an operating lease if a purchase is not possible. The manager intended to pay off the bank loan before any major expansion of the business. The manager relied heavily on the accountant's advice on any major purchase for the business since he is very careful about the company's debt covenant. When questioned whether the change of the accounting standards is going to impact their decision on lease term, and the manager said: "We will rely on our accountants' expertise." The manager said they mainly focused on the growth of the business, but had little knowledge about accounting standards and the tax code. "The business has 12 employees, and we cannot afford to hire someone full time to manage our books. It is much cheaper for us to hire an accountant on a fee basis than to have a full time accountant or bookkeeper.” The manager did not incorporate the cost of implementation of the new accounting standards change to the company's business operation, but he was more concerned about the immediate cost and benefits, such as interest rate and tax benefits.

All managers are not very familiar with principles-based International Financial Reporting Standards, and they rely on the external accountants to provide expertise on the implementation of the new principles. Management is more interested in the tax benefits, such as qualified "section 179" equipment and property purchase to increase the immediate expense and reduce tax liability. Finally, management would consider the classification of the lease if the entity were subject to debt covenant. The research suggests the adoption of IFRS in lease accounting is not a major determinant for managements' consideration in business operation. Rather, they are generally more interested in potential tax liabilities since that impacts the cash flow in the foreseeable future. If FASB can incorporate IRS input for the new accounting standards, the fair presentation of financial statements can be more effective (Figure 1).

\section{Conclusions \& Implications}

The research attempts to bridge the gap between the understanding between small- and medium-sized entities and the adoption of International Financial Reporting Standards. Many studies focus on the auditors' judgment, financial users reaction, and regulatory agency's cost benefit, but little is known about the management's perception. This research interviewed four managers and gained knowledge about the train of thoughts during the acquisition of plant and machinery. Most SMEs are family-owned business, and the corporations' principalagent conflict model is at its minimal. The managers' goal is to survive and expand the firms, and pass down the business to their heir. The managers normally do not possess the accounting expertise, so they rely heavily on the accountant to assist them with financial statements and tax returns [20]. In order to improve the presentation of financial statement in accordance of IFRS, the accountants need to sharpen their skills and equip knowledge about the IFRS adoption.

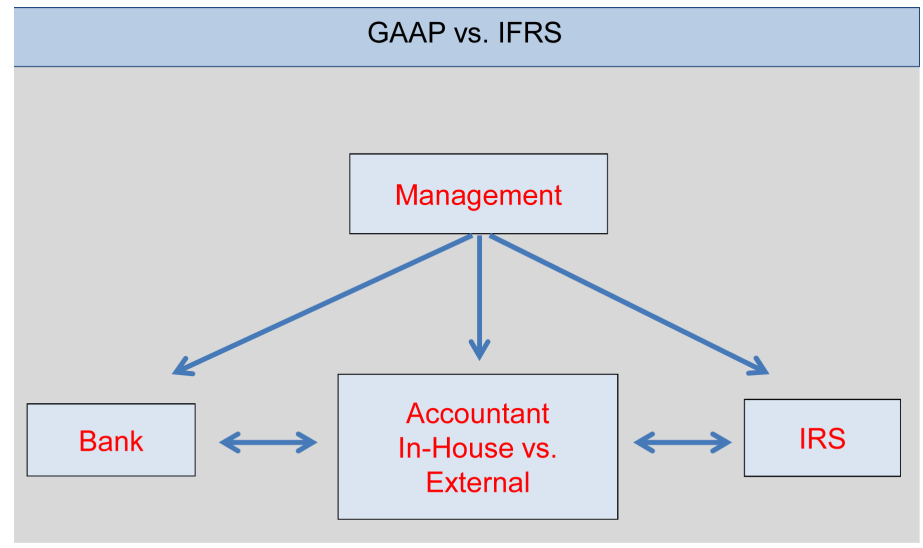

Figure 1. Interaction between management and external users. 
The managements are also interested in the tax consequences after the IFRS implementation. The current IFRS adoption does not incorporate any tax code changes. The SMEs guard their cash flow carefully, one of which is tax payment. If FASB can work with IRS, the implementation of IFRS might go more smoothly. The cooperation between multiple departments would be the ideal environment to adopt, implement, and improve the convergence of accounting standards.

\section{References}

[1] Shortridge, R.T. and Myring, M. (2004) Defining Principles-Based Accounting Standards. The CPA Journal Online. http://www.nysscpa.org/cpajournal/2004/804/essentials/p34.htm

[2] Nelson, M.W. (2003) Behavioral Evidence on the Effects of Principles- and Rules-Based Standards. Accounting Horizons, 17, 91-104. http://dx.doi.org/10.2308/acch.2003.17.1.91

[3] Barth, M.E. and Schipper, K. (2008) Financial Reporting Transparency. Journal of Accounting, Auditing \& Finance, 23, 173-190.

[4] Daske, H., Hail, L., Leuz, C. and Verdi, R. (2008) Mandatory IFRS Reporting around the World: Early Evidence on the Economic Consequences. Journal of Accounting Research, 46, 1085-1142.

[5] Diehl, K.A. (2010) The Real Cost of IFRS: The Relationship between IFRS Implementation and Audit, Tax, and Other Auditor Fees. International Research Journal of Finance \& Economics, No. 37, 96-101.

[6] Barbera, F. and Hasso, T. (2013) Do We Need to Use an Accountant? The Sales Growth and Survival Benefits to Family SMEs. Family Business Review, 26, 271-292. http://dx.doi.org/10.1177/0894486513487198

[7] Maines, C.L.A., Bartov, E., Fairfield, P., Hirst, D.E., Iannaconi, T.E., Mallett, R., Schrand, C.M., Skinner, D.J. and Vincent, L. (2003) Evaluating Concepts-Based vs. Rules-Based Approaches to Standard Setting. Accounting Horizons, 17, 73-89. http://dx.doi.org/10.2308/acch.2003.17.1.73

[8] Agoglia, C.P., Doupnik, T.S. and Tsakumis, G.T. (2011) Principles-Based versus Rules-Based Accounting Standards: The Influence of Standard Precision and Audit Committee Strength on Financial Reporting Decisions. Accounting Review, 86, 747-767. http://dx.doi.org/10.2308/accr.00000045

[9] Zéghal, D., Chtourou, S. and Sellami, Y.M. (2011) An Analysis of the Effect of Mandatory Adoption of IAS/IFRS on Earnings Management. Journal of International Accounting, Auditing \& Taxation, 20, 61-72. http://dx.doi.org/10.1016/j.intaccaudtax.2011.06.001

[10] Chua, Y.L., Cheong, C.S. and Gould, G. (2012) The Impact of Mandatory IFRS Adoption on Accounting Quality: Evidence from Australia. Journal of International Accounting Research, 11, 119-146. http://dx.doi.org/10.2308/jiar-10212

[11] Iatridis, G. (2010) International Financial Reporting Standards and the Quality of Financial Statement Information. International Review of Financial Analysis, 19, 193-204.

[12] Karamanou, I. and Nishiotis, G.P. (2009) Disclosure and the Cost of Capital: Evidence form the Market's Reaction to Firm Voluntary Adoption of IAS. Journal of Business Finance \& Accounting, 36, 793-821. http://dx.doi.org/10.1111/j.1468-5957.2009.02154.x

[13] Psaros, J. and Trotman, K.T. (2004) The Impact of the Type of Accounting Standards on Preparers' Judgments. Abacus, 40, 76-93. http://dx.doi.org/10.1111/j.1467-6281.2004.00144.x

[14] Dechow, P.M. and Sloan, R.G. (1995) Detecting Earnings Management. Accounting Review, 70, 193-225.

[15] Cohen, D., Darrough, M.N., Huang, R. and Zach, T. (2011) Warranty Reserve: Contingent Liability, Information Signal, or Earnings Management Tool? The Accounting Review, 86, 569-604. http://dx.doi.org/10.2308/accr.00000021

[16] Bens, D.A., Heltzer, W. and Segal, B. (2011) The Information Content of Goodwill Impairments and SFAS 142. Journal of Accounting, Auditing \& Finance, 26, 527-555. http://dx.doi.org/10.1177/0148558X11401551

[17] Gibbins, M., Salterio, S. and Webb, A. (2001) Evidence about Auditor-Client Management Negotiation Concerning. Journal of Accounting Research, 39, 535-563. http://dx.doi.org/10.1111/1475-679X.00027

[18] Tan, H., Wang, S. and Welker, M. (2011) Analyst Following and Forecast Accuracy after Mandated IFRS Adoptions. Journal of Accounting Research, 49, 1307-1357. http://dx.doi.org/10.1111/j.1475-679X.2011.00422.x

[19] Dargenidou, C. and McLeay, S. (2010) The Impact of Introducing Estimates of the Future on International Comparability in Earnings Expectations. European Accounting Review, 19, 511-534. http://dx.doi.org/10.1080/09638180.2010.496550

[20] Vasek, L. (2011) IFRS for SMES-A New Challenge for Worldwide Financial Reporting. International Journal of Management Cases, 13, 115-120. http://dx.doi.org/10.5848/APBJ.2011.00118 
Scientific Research Publishing (SCIRP) is one of the largest Open Access journal publishers. It is currently publishing more than 200 open access, online, peer-reviewed journals covering a wide range of academic disciplines. SCIRP serves the worldwide academic communities and contributes to the progress and application of science with its publication.

Other selected journals from SCIRP are listed as below. Submit your manuscript to us via either submit@scirp.org or Online Submission Portal.
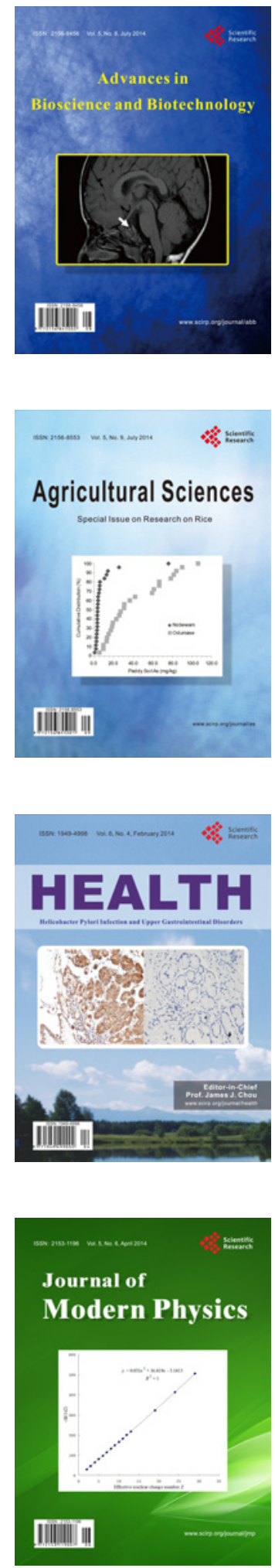
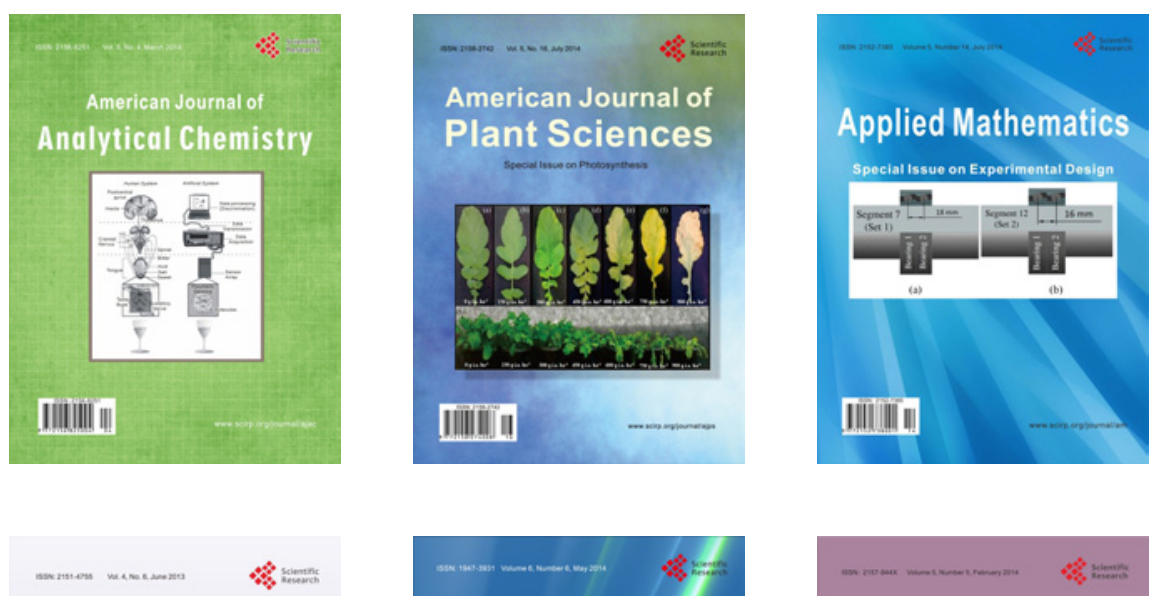

Creative Education
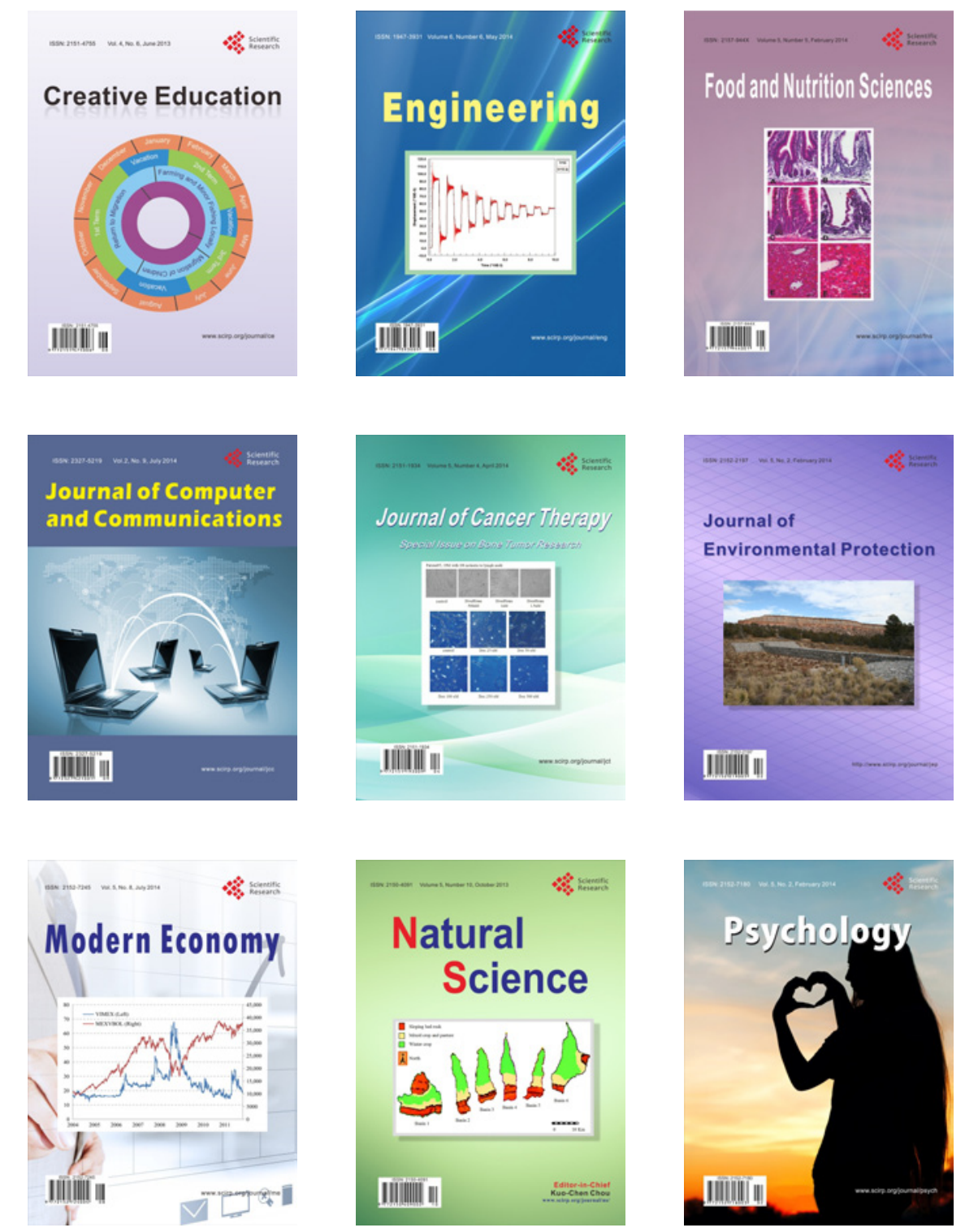